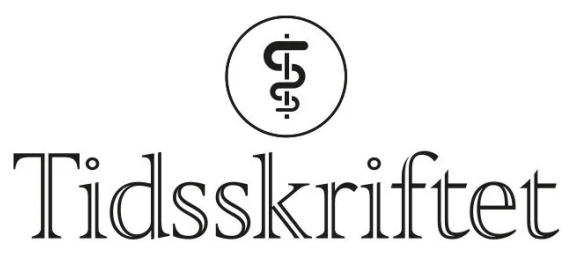

DEN NORSKE LEGEFORENING

\title{
Pårørende til pasienter med covid-19 trenger oss
}

DEBATT

\section{KJELL ERIK STRøMSKAG}

kjeer-st@online.no

Kjell Erik Strømskag er spesialist i anestesiologi og overlege ved Molde sjukehus. Forfatteren har fylt ut ICMJE-skjemaet og oppgir ingen interessekonflikter.

\section{RIGMOR OPSTAD}

Rigmor Opstad er intensivsykepleier ved Molde sjukehus.

Forfatteren har fylt ut ICMJE-skjemaet og oppgir ingen interessekonflikter.

\section{Pasienter, pårørende og intensivpersonell er i en uvant situasjon under covid-19-pandemien. Kontakten med de pårørende må sikres.}

Pårørendes plass og rolle på intensivavdelingene har endret seg mye de to siste tiårene. Fra å ha begrenset adgang til avdelingene og manglende nærhet til sine nærmeste har ektefelle, partner, mor, far, søsken og noen ganger nære venner blitt en viktig del av behandlingen og omsorgen. Intensivpersonell har både kunnskap og forståelse for dagens praksis, der nesten fri tilgang til informasjon og nærvær er en del av behandlingen. Dette er særlig viktig i usikre og eksistensielle situasjoner. Å involvere pårørende er en like stor del av sykepleiernes og legenes faglige grunnlag som kunnskap om riktig antibiotika og korrekt dosering av noradrenalin. Vi har registrert få artikler eller innslag om pårørendes plass i forbindelse med behandling av covid-19-syke pasienter (1).

\section{Pårørendes behov}

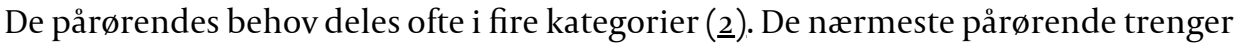
kognitiv, emosjonell, sosial og praktisk støtte. Behovet for god og forståelig medisinsk informasjon er nesten ubegrenset. Denne informasjonen bør gis ansikt til ansikt av en lege som i det daglige har ansvar for pasienten. I tillegg må sykepleierne gi informasjon om stell og prosedyrer.

Før pårørende går inn på intensivrommet må de forberedes. De må informeres om hva de kommer til å få se og særlig om hvordan deres kjære ser ut. Når de pårørende sitter inn hos pasienten, er det viktig at de blir informert om det tekniske utstyret og får forklart hvorfor 
alle ledninger, slanger, pumper osv. er viktige.

Ved alle viktige endringer hos pasienten skal pårørende kontaktes. Eventuelle praktisk behov blir kartlagt, og et vanlig spørsmål er hva de pårørende tror er viktig for pasienten $\mathrm{i}$ denne situasjonen. Fundamentet for all pårørende kontakt er at informasjon skal være korrekt, realistisk og samtidig bringe håp inntil alt håp er ute (3).

\section{Utfordringer ved covid-19}

Som helsepersonell på intensivavdelinger er vi vant til å forholde oss til alvorlig syke og døende pasienter. Det er krevende, men vi har gode rutiner og flinke helsearbeidere med lang erfaring. Men covid-19 er noe annet. Den utfordrer vår oppfatning av gullstandard for god omsorg.

\section{«Noen av oss foreslo at sykehuset burde planlegge og etablere et mottak for pårørende»}

Det er særlig fire forhold som gjør det ekstra krevende. For det første er totalsituasjonen nasjonalt og internasjonalt ny og utfordrende. Det er lagt strenge reguleringer og begrensninger i livene våre, og mange av oss er usikre og redde. Det gjelder også de pårørende. For det andre gjør karantenetiltakene at pårørende isoleres i den kanskje vanskeligste perioden i livene deres. For det tredje er selve sykdommen og utviklingen annerledes og skremmende. Forverring av lungefunksjon går fort og er dramatisk. For det fjerde gjør smitteregimet at de nærmeste ikke får komme på avdelingen og sitte ved sengen. De er faktisk så strengt at de får ikke komme inn på sykehuset. Denne avstanden både geografisk og organisatorisk er en utfordring i seg selv. Den fører til en femte utfordring, som gjelder behovet for å se og ta på den kjære. Alt dette forsterkes dersom pasienten $\mathrm{d} \emptyset \mathrm{r}$.

\section{Slik gjør vi det ved Molde sjukehus}

Vi ble tidlig klar over den nye situasjonen for pasient, pårørende og pårørendeomsorg, og den bekymret oss. Etter at de viktige store grepene med alle smittetiltak, organisering og tilrettelegging på Intensivavdelingen samt opprettelse av kohortavdeling for pasienter med covid-19, foreslo derfor noen av oss at sykehuset burde planlegge og etablere et mottak for pårørende. Forslaget fikk umiddelbart støtte av ledelsen, og det ble funnet gode lokaler. En erfaren anestesilege og intensivsykepleier fikk ansvar for å organisere tilbudet i samarbeid med seksjonsleder ved Intensivavdelingen.

Til å begynne med var det ikke noe tidspress, ettersom de pårørende satt i karantene og den daglig informasjonen ble gitt per telefon. Lokalene vi fant, har en egnet størrelse, ligger isolert fra resten av sykehuset og har egen inngang. Samtidig er de knyttet til hovedhuset, slik at intensivpersonell kan gå tørrskodd mellom bygningene. Det er pc-er med tilgang til journal og annen informasjon. Møbleringen er slik at nødvendig avstand kan holdes selv med fem personer til stede. Dette gir mulighet for at pårørende kan møte de som behandler og steller pasienten. Vi som organiserer tilbudet, er der uten noen form for tidsbegrensninger, også utenom normal arbeidstid. Hovedansvarlig for tilbudet vil så lenge det er mulig være unntatt direkte klinisk arbeid. Det er også muligheter for audiovisuell kontakt mellom pasient og pårørende. I starten foregikk dette via smarttelefoner. Litt å spise og drikke er selvfølgelig tilgjengelig.

De foreløpige erfaringene med tilbudet er svært positive. Både pårørende og de pasientnære helsearbeiderne har uttrykt glede og lettelse over endelig å kunne møtes ansikt til ansikt. Det ble en annen ro over informasjonen og lettere å stille oppfølgende 
spørsmål. Det var et høydepunkt når pasient og pårørende kunne kommunisere via skjerm, med konkret informasjon og veiledning for de pårørende både før, under og etter samtalen.

\section{LITTERATUR}

1. Frivold G, Lind R. Pårørende kan rammes hardt. Dagens Medisin 31.3.2020. https://www.dagensmedisin.no/artikler/2020/03/31/parorende-kan-rammes-hardt Lest 1.4.2020.

2. Verhaeghe S, Defloor T, Van Zuuren F et al. The needs and experiences of family members of adult patients in an intensive care unit: a review of the literature. J Clin Nurs 2005; 14: 501-9. [PubMed] [CrossRef]

3. Verhaeghe ST, van Zuuren FJ, Defloor T et al. How does information influence hope in family members of traumatic coma patients in intensive care unit? J Clin Nurs 2007; 16:1488-97. [PubMed] [CrossRef]

Publisert: 7. april 2020. Tidsskr Nor Legeforen. DOI: 10.4045/tidsskr.20.0294

Mottatt 2.4.2020, første revisjon innsendt 3.4.2020, godkjent 3.4.2020.

(C) Tidsskrift for Den norske legeforening 2023. Lastet ned fra tidsskriftet.no 26. april 2023. 